\title{
The response of phytoplankton in a subtropical lake to the cessation of aquaculture: a case study of Lake Dianshan, China
}

\author{
Gaohua $\mathrm{Ji}^{1,2 *}$, Li Xu ${ }^{3}$, Liqing $\mathrm{Wang}^{2}$, Zuxin $\mathrm{Xu}^{1}$, Xiaojie Dai ${ }^{4}$ and Ruilei Zhang ${ }^{2}$ \\ 1 College of Environmental Science and Engineering, Tongji University, Shanghai, China \\ 2 College of Fisheries and Life Science, Shanghai Ocean University, Shanghai, China \\ 3 National Ocean Technology Center, State Oceanic Administration, Tianjin, China \\ ${ }^{4}$ College of Marine Sciences, Shanghai Ocean University, Shanghai, China
}

Received 30 January 2015; Accepted 9 December 2016

\begin{abstract}
To assess the effectiveness of aquaculture cessation for improving water quality, we analysed the response of the phytoplankton community to the cessation of aquaculture in Lake Dianshan, Shanghai, China. Quantitative analyses of phytoplankton and nutrient content were undertaken monthly from 2004 through 2008. After the cessation of aquaculture, no significant changes in nutrient concentration were detected. Nevertheless, the phytoplankton community changed greatly after the cessation. Firstly, the phytoplankton species richness as well as the Shannon-Wiener diversity index increased. Secondly, the chlorophylla concentration and the phytoplankton density declined sharply. This decrease was caused primarily by a decrease in Cyanophyta. Additionally, the Chlorophyta, Bacillariophyta and Cryptophyta increased, leading to a decrease in the relative biomass of Cyanophyta. Thirdly, the dominant species shifted from the toxic cyanophyte Microcystis sp. to less harmful Cyanophyta such as Merismopedia sp. and Chroococcus sp., along with Chlorophyta, Bacillariophyta and Cryptophyta. The phytoplankton community composition improved, indicating that the overall water quality was improved after the cessation. However, the changes in the phytoplankton community were more likely to be associated with the physical and biotic changes caused by the removal of aquaculture than with the variation in nutrient levels. Our study indicated that phytoplankton monitoring, especially in summer, is essential for assessing the water quality because an overall improvement in water quality may also be achieved without significant changes in nutrient concentrations. The rebounding of Cyanophyta in 2008 highlighted the importance of controlling nutrient loading by inflow for a substantial improvement in water quality. These results are relevant for managing subtropical eutrophic lakes.
\end{abstract}

Key words: Phytoplankton / aquaculture cessation / subtropical lake / water quality

\section{Introduction}

Inland waters, such as lakes and reservoirs, are frequently influenced by aquaculture. As the major method of intensive fish culturing, cage aquaculture (the culturing of fish at high densities using manufactured feed and net cages or enclosures in lakes or reservoirs) has been a strongly developing sector of freshwater fish husbandry for many decades (Brander, 2007). In 2004, approximately 939700 hectares (ha) of Chinese inland lakes were involved in fishery activities, producing a total of 1147000 tonnes (t) of food (mass). Within these lakes, $10 \%$ by area was devoted to cage aquaculture, but this subset contributed $21 \%$ of the total production (Chen and Guan, 2006). However, similarly to any other productive

\footnotetext{
*Corresponding author: ghji@shou.edu.cn
}

activity, cage aquaculture can cause environmental problems, including nutrient loading from the waste that is directly discharged into the water (residual food and faeces). It causes eutrophication and disharmony in the aquatic ecological balance and may lead further to a decline in biodiversity, introduction of exotic species and the spread of fish pathogens (Naylor et al., 2000; Nash, 2001; Guo and Li, 2003; Figueredo and Giani, 2005; Guo et al., 2009).

There are several assessments of the effect of cage aquaculture on the aquatic environment in China (Liu et al., 1997; Guo and Li, 2003; Zhang et al., 2004; Xu et al., 2007; Guo et al., 2009), most of which focused on the environmental pollution caused by cultivation. Furthermore, the cultivated fish in lakes can also influence the plankton community through both top-down and bottom-up impacts, depending on their feeding habits 
(Lazzaro et al., 2003). Filter-feeding fish such as silver carp (Hypophthalmichthys molitrix) and bighead carp (Aristichthys nobilis) are considered predators of both phytoplankton and zooplankton and may reduce the numbers of cladocerans. Omnivorous fish, especially cyprinids, can be considered to function as nutrient pumps. They return phosphorus and nitrogen from the sediment to the water column. In previous studies, they were found to increase turbidity and the availability of important nutrients (Perrow et al., 1997; Hansson et al., 1998; Meijer et al., 1999), and their presence tends to increase phytoplankton abundance (Shapiro et al., 1975; Olin et al., 2006). Generally, aquaculture is considered to have a negative effect on water quality. Nutrient loading and a decrease in the numbers of large zooplankton may cause harmful algal blooms in lakes. In China, the responsible managers have recognized the problem and have taken measures to alleviate pollution. Cage aquaculture has been banned or reduced in some lakes, usually those with low environmental carrying capacities. Water quality is expected to benefit from these measures.

The phytoplankton community is typically diverse and is made up of organisms that are highly sensitive to changes in the environment. These organisms can be used as a bio-indicator of environmental changes caused by anthropogenic factors (Pinto-Coelho et al., 2005; Sin and Jeong, 2015). The removal of aquaculture would reduce nutrient loading, clear barriers in the lake and change the fish community structure. These changes can consequently give rise to changes in phytoplankton species composition and biomass, but detailed assessments of this process are scarce. The present study aims to assess the responses of nutrient concentration and phytoplankton community to aquaculture cessation in Lake Dianshan, a subtropical lake in Eastern China. Because lakes near cities are often highly managed for multiple goals, including flood control, navigation, water supply, irrigation, recreation, and fish and wildlife, management actions commonly involve restrictions on aquaculture and stock enhancement, which potentially structures the phytoplankton community via trophic cascade effects. Qualitative and quantitative phytoplankton dynamics in lakes have strong implications for water quality management.

\section{Materials and methods}

\section{Study area and fisheries activities}

Lake Dianshan is located in the lower reaches of the Yangtze River and is part of a dish-like depression of Taihu Lake Plain, China (Fig. 1). It is a shallow, subtropical freshwater lake and the main water source of the city of Shanghai. It has an area of $63.7 \mathrm{~km}^{2}$. Its average and maximum depths are 2.1 and $3.6 \mathrm{~m}$, respectively. The lake surface is $2.63 \mathrm{~m}$ above sea level. It receives water from Lake Taihu and discharges into the East China Sea via rivers. The water flows at a velocity of $0.02 \mathrm{~m} . \mathrm{s}^{-1}$ to the southeast in the lake. The hydraulic residence time of the lake is 29 days. The lake has multiple uses, including supplying water, recreation, fishing, irrigation, flood storage and waterborne transportation. The lake was used for intensive fish production before 2004, especially around S2 and S3 (Fig. 1). There is a park near S2 with restaurants and yachts. There are also many villages, towns and factories around the lake. Macrophytes are rare and distributed only in the littoral zone.

The lake was dominated by cage aquaculture between 1985 and 2005. Various installations for aquaculture, such as net cages, bamboo enclosures and polyethylene nets, were deployed in the lake. Most fish production took place through active culture involving feeding, and wild fish were rare because traps (collapsible pots and bamboohedge traps) were placed throughout the lake to catch fish. The total area of cage aquaculture was approximately 867 ha, which was $14 \%$ of the lake area, and most aquaculture was distributed in the areas around S3 and S6. The average net fish production was approximately $3750 \mathrm{~kg} \cdot \mathrm{ha}^{-1}$, and the food conversion ratio was approximately 2.4 (Shi and Liu, 1989). Net nitrogen and phosphorus inputs per year into the entire lake were estimated at 161 and $26 \mathrm{t}$, respectively, with $61 \%$ of both occurring in summer (Shi and Liu, 1989). The main types of breeding fishes belonged to the Cyprinidae, including Ctenopharyngodon idella, Mylopharyngodon piceus, Parabramis pekinensis, H. molitrix, A. nobilis and Carassius auratus.

Cyanobacterial blooms occurred frequently, producing toxic microcystins (Ding et al., 1999). Accordingly, the government mandated and enforced a cessation of aquaculture to reduce pollution, and this initiative was completed in May 2005. Fingerling and juvenile fish have been released into the lake every spring since 2004 to bolster the wild fish population, with no supplemental feeding. To conserve fishery resources, an annual ban on fishing was enforced in the lake during the breeding season, from February 16 to August 15.

From 2004 to 2007, the total weight of released fish increased steadily, but it decreased in 2008 (Table 1). The species composition of released fish was similar from 2006 through 2008. Silver carp and bighead carp made up a large proportion ( $41.2 \%$ on average) in weight. However, other omnivorous cyprinids, including Cyprinus carpio, C. auratus and Hemibarbus maculatus, were also present in large proportions. The proportion of carnivorous fish released was relatively small (Table 1 ).

\section{Sampling}

Six sampling stations have been established in the lake (S1-S6). S1 is near the main outlet, and S5 is near the main inlet. S2, S3 and S6 are near the decommissioned cage aquaculture farms.

Samples of water and plankton were taken monthly from January 2004 to December 2008, except for February 2005. A total of 354 samples were collected in this study. A $10 \mathrm{~L}$ integrated sample was collected with a $5 \mathrm{~L}$ Perspex 


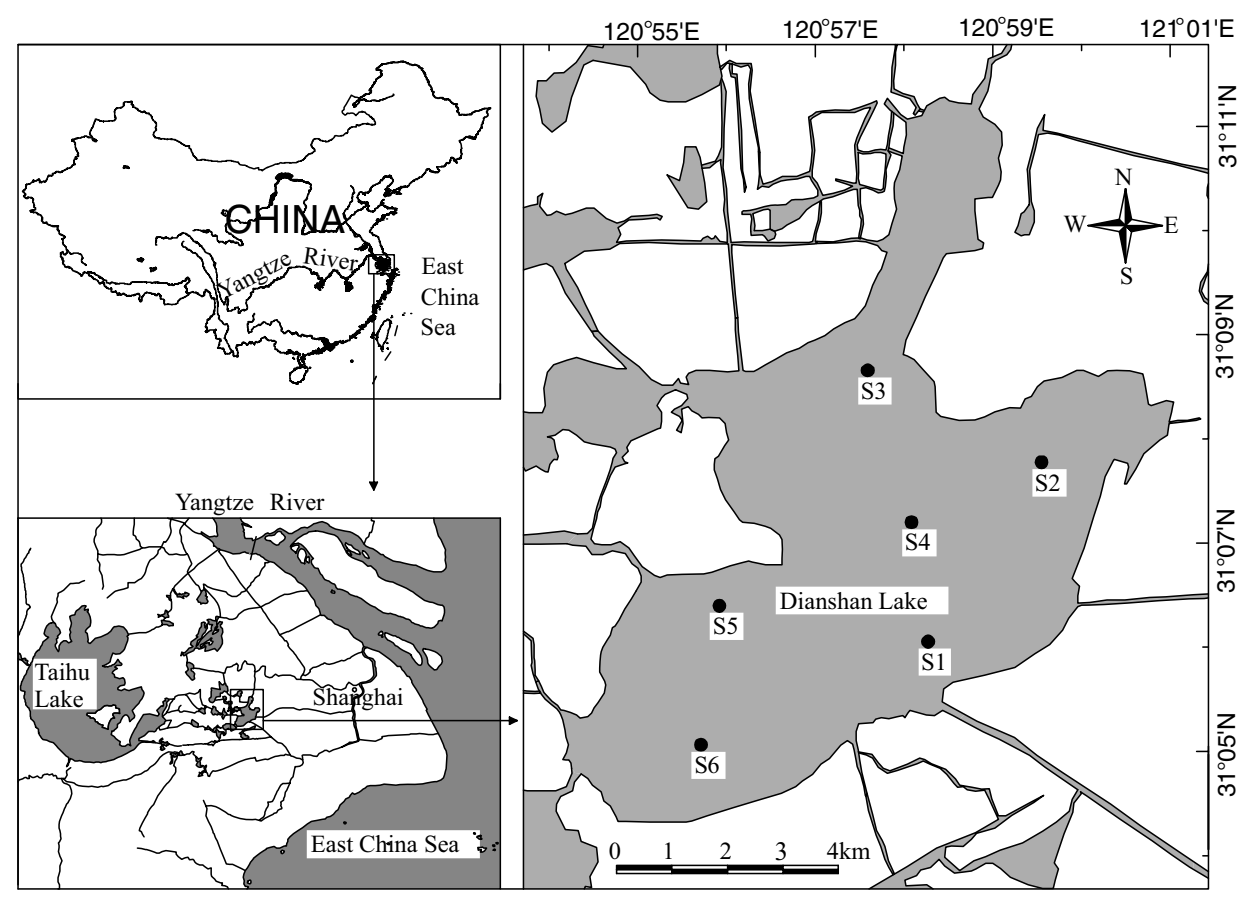

Fig. 1. Location of Lake Dianshan, China and the sampling stations.

Table 1. Numbers $\left(\times 10^{3}\right)$ and weights $(\mathrm{kg})$ of released fish from 2004 to 2008 in Lake Dianshan (data from the local fisheries administration).

\begin{tabular}{|c|c|c|c|c|c|c|c|c|c|c|}
\hline \multirow[b]{2}{*}{ Fish species } & \multicolumn{2}{|c|}{2004} & \multicolumn{2}{|c|}{2005} & \multicolumn{2}{|c|}{2006} & \multicolumn{2}{|c|}{2007} & \multicolumn{2}{|c|}{2008} \\
\hline & Number & Weight & Number & $\overline{\text { Weight }}$ & $\overline{\text { Number }}$ & $\overline{\text { Weight }}$ & $\overline{\text { Number }}$ & $\overline{\text { Weight }}$ & $\overline{\text { Number }}$ & Weight \\
\hline$\overline{H .}$ molitrix (juvenile) & $\overline{0}$ & 0 & 212 & 14469 & 303 & 17279 & 434 & 29313 & 263 & 10938 \\
\hline H. molitrix (summerlings) & 3750 & 1875 & 3750 & 1875 & 3750 & 852 & 11250 & 2557 & 11250 & 2557 \\
\hline A. nobilis (juvenile) & 0 & 0 & 86 & 4823 & 146 & 5607 & 225 & 8104 & 87.5 & 3646 \\
\hline A. nobilis (summerlings) & 1250 & 625 & 1250 & 625 & 1250 & 284 & 3750 & 852 & 3750 & 852 \\
\hline Cy. carpio (juvenile) & 0 & 0 & 84 & 3818 & 441 & 22015 & 385 & 20783 & 25 & 2722 \\
\hline Cy. carpio (summerlings) & 2500 & 4167 & 2500 & 4167 & 2500 & 4167 & 4000 & 6667 & 5000 & 8333 \\
\hline Ca. auratus (summerlings) & 7500 & 4688 & 7500 & 4688 & 7500 & 3191 & 6000 & 2553 & 12500 & 5319 \\
\hline E. ilishaeformis & 0 & 0 & 0 & 0 & 478 & 10583 & 81 & 2700 & 200 & 1333 \\
\hline He. maculatus & 50 & 2500 & 50 & 2500 & 150 & 3000 & 340 & 12500 & 350 & 17500 \\
\hline S. chuatsi & 100 & 56 & 100 & 56 & 120 & 80 & 140 & 93 & 140 & 93 \\
\hline Pelteobagrus fulvidraco & 0 & 0 & 0 & 0 & 100 & 833 & 100 & 833 & 100 & 833 \\
\hline Total & 15150 & 13910 & 15532 & 37020 & 16738 & 67893 & 26704 & 86955 & 33665 & 54127 \\
\hline
\end{tabular}

sampler at 0.5 and $1.5 \mathrm{~m}$ at each station and mixed in a plastic bucket. A $1 \mathrm{~L}$ subsample was taken for nutrient analyses. Total phosphorus (TP) was analysed using persulphate digestion and the ascorbic acid method. Soluble reactive phosphorus (SRP) was determined by the ascorbic acid method. Total nitrogen (TN) determination used persulphate digestion and ultraviolet spectrophotometry. Nitrate-nitrogen $\left(\mathrm{NO}_{3}\right)$ was measured by $\mathrm{Cd}$ reduction and the diazotization method. Nitrite-nitrogen $\left(\mathrm{NO}_{2}\right)$ was measured using diazotization. Ammoniumnitrogen $\left(\mathrm{NH}_{4}\right)$ was measured using nesslerization. Chemical oxygen demand $\left(\mathrm{COD}_{\mathrm{Mn}}\right)$ was analysed by the potassium permanganate index method. Chlorophyll-a (chl-a) was determined spectrophotometrically after filtration on Whatman $\mathrm{GF} / \mathrm{C}$ glass filters and extraction with cold 90\% acetone (APHA, 1998; State EPA of
China, 2002). Water transparency (SD) was estimated using a standard Secchi disc $20 \mathrm{~cm}$ in diameter. Water temperature (Tem) was measured using a mercury thermometer.

Another $1 \mathrm{~L}$ subsample taken from the integrated sample for phytoplankton and rotifers was preserved with Lugol's solution and formaldehyde, and counted under an optical microscope after sedimentation and concentration (Jin and Tu, 1990; APHA, 1998; Lu et al., 2002). Algal taxa were identified according to $\mathrm{Hu}$ and Wei (2006), $\mathrm{Hu}$ et al. (1980) and a series of books on the freshwater algal flora of China. At least 400 cells were counted in each sample. Algal biomass (wet weight) was estimated by considering algal cells to be equivalent geometric shapes (Hillebrand et al., 1999) and assuming their specific gravity to be unity (Zhao et al., 2012). All phytoplankton taxa 
were grouped into one of three size classes based on the greatest axial linear dimension (GALD): edible phytoplankton (GALD $<20 \mu \mathrm{m})$ and large inedible phytoplankton (GALD $>70 \mu \mathrm{m})$ for zooplankton and the intermediate group $(20 \mu \mathrm{m}<\mathrm{GALD}<70 \mu \mathrm{m})$. Phytoplankton carbon content $\left(\mu \mathrm{gC} . \mathrm{L}^{-1}\right)$ was estimated with the following equation: carbon contents $=$ wet weight $\times 1000 \times 0.2 \times 0.4 \quad$ (Behrendt, 1990). For the micro-crustaceans, samples were collected by filtering $20 \mathrm{~L}$ of water sampled at 0.5 and $1.5 \mathrm{~m}$ through a plankton net with a mesh size of $64 \mu \mathrm{m}$, followed immediately by preservation with $4 \%$ formaldehyde. Zooplankton counting was performed under a microscope using a $1 \mathrm{~mL}$ Sedgewick-Rafter chamber and were identified mainly according to the available guides to the rotifer, cladoceran and copepod fauna of China as well as with other books (Wang, 1961; Chiang and Du, 1979; Shen, 1979; Zhuge et al., 1998). The biomass of crustaceans was estimated from length-dry weight regressions (Dumont et al., 1975; McCauley, 1984; Culver et al., 1985). Biomass for rotifers was obtained assuming a specific gravity of 1 and dry weight/wet weight ratio of 0.1 (McCauley, 1984). Zooplankton carbon content was assumed to be $50 \%$ of the dry weight (Latja and Salonen, 1978). The dominant species were defined as those that contributed at least $10 \%$ to the total biomass in at least 1 month. The Shannon-Wiener index $\left(H^{\prime}\right)$ was used to calculate species diversity and calculated using the formula $H^{\prime}=-P_{i} \Sigma \log _{2} P_{i}$, where $P_{i}$ represents the proportion of individuals belonging to the $t$ th species.

\section{Statistical analysis}

The data collected from the six stations in each month were averaged to reduce the influence of spatial variability. Analysis of variance (ANOVA) was used to test statistical significance for the differences between samples among months or years, followed by Scheffe's test if needed. The significance level used was $\alpha=0.05$. Principal component analysis (PCA) was used to examine temporal variability in the physical and chemical parameters. All nine of the above-mentioned variables that were sampled simultaneously with the phytoplankton were included in the analysis $(\log (x+1)$ transformed data $)$.

A canonical correspondence analysis (CCA) was used to explore the main variables affecting the structure of the phytoplankton community because a preliminary detrended correspondence analysis indicated that the longest species gradient was larger than 4 (Lepš and SŠmilauer, 2003). For this analysis, we used the phytoplankton community data (biomass of the dominant species) and the 10 abiotic variables on 59 sampling occasions, with 30 dominant species $(\log (x+1)$ transformed data). The statistical significance of the first and all the ordination axes was tested using a Monte Carlo permutation test (4999 unrestricted permutations). The ordinations were performed using CANACO for Windows 4.5 (Lepš and Smilauer, 2003).

\section{Results}

\section{Abiotic variables}

The physical and chemical parameters during the study period are summarized in Table 2. There was no significant difference in water temperature across different years, but it changed dramatically by month (Table 2 , Fig. 2). The highest water temperature each year was recorded in July or August. Water transparency also exhibited strong monthly fluctuations and was negatively correlated with temperature $(P<0.01)$, but was similar between years. Considering the large monthly fluctuation of all variables, a two-way ANOVA was conducted to evaluate differences between years. This analysis compared the same month in different years.

Overall, the nutrient concentrations showed no significant differences before and after the cessation of cage aquaculture; however, some indices showed outlying values in individual years. With regard to nitrogen, different forms exhibited different trends. Ammonium values dropped slightly in 2005, then rebounded in 2006 and 2007 (Table 2), and then showed significant decreases in 2008. Nitrite concentrations displayed an increasing trend with significantly higher values in 2007 and 2008. Nitrate concentrations decreased in the first 2 years after cessation but increased in the last 2 years. The variation of TN was similar to ammonium, with higher values in 2006 and 2007 (Table 2). Phosphorus fluctuated in a different way: SRP values were significantly higher in 2005 , but then decreased. TP concentrations were also higher in 2005 and decreased in 2006, but increased again in the final 2 years. Thus, the TN:TP ratios were highest in 2005 and lowest in 2008. $\mathrm{COD}_{\mathrm{Mn}}$ was at a significantly low level in 2006.

The PCA of environmental variables highlighted that the seasonal fluctuations were greater than annual fluctuations (Fig. 3). Nutrient levels were generally higher in spring and winter than in summer or autumn. Considering the strong effect of temperature, we divided the year into two periods: the warm period (May-October, temperature $>20^{\circ} \mathrm{C}$ ) and the cold period (NovemberApril, temperature $<20^{\circ} \mathrm{C}$ ). The samples collected in 2004 were scattered among the samples collected after cessation, which indicated that the overall nutrient levels were similar. However, the nutrient level during the summer of 2006 was higher than others along the nitrogen gradient. The first two components explained $73.5 \%$ of the variance in the environmental data. The first axis was associated with the concentrations of $\mathrm{TN}$ and temperature, and the variables most influencing the second PCA axis were $\mathrm{SD}, \mathrm{NO}_{2}, \mathrm{NO}_{3}$ and $\mathrm{NH}_{4}$.

\section{Phytoplankton community variation}

Over the course of the study, the phytoplankton community of Lake Dianshan was composed of 226 taxa belonging to 89 genera. Chlorophyta was the group richest in species, followed by Bacillariophyta and Cyanophyta. 
Table 2. Water quality variables (means \pm SD) in Lake Dianshan from 2004 to 2008 .

\begin{tabular}{|c|c|c|c|c|c|c|}
\hline Variable & Abbreviation & 2004 & 2005 & 2006 & 2007 & 2008 \\
\hline Water temperature $\left({ }^{\circ} \mathrm{C}\right)$ & Tem & $18.2 \pm 9.09$ & $18.7 \pm 9.05$ & $17.7 \pm 8.98$ & $17.3 \pm 8.47$ & $17.0 \pm 8.75$ \\
\hline Water transparency $(\mathrm{cm})$ & SD & $46.3 \pm 12.6$ & $40.8 \pm 15.8$ & $40.6 \pm 11.4$ & $39.5 \pm 7.01$ & $41.1 \pm 8.18$ \\
\hline Chemical oxygen demand (mg. $\mathrm{L}^{-1}$ ) & $\mathrm{COD}_{\mathrm{Mn}}$ & $6.55 \pm 1.16^{\mathrm{ab}}$ & $6.02 \pm 2.10^{\mathrm{ab}}$ & $4.69 \pm 0.57^{\mathrm{b}}$ & $7.08 \pm 2.09^{\mathrm{ab}}$ & $7.42 \pm 2.18^{\mathrm{a}}$ \\
\hline Ammonium-nitrogen (mg. $\mathrm{L}^{-1}$ ) & $\mathrm{NH}_{4}$ & $1.91 \pm 1.75^{\mathrm{abc}}$ & $1.39 \pm 0.77^{\mathrm{bc}}$ & $2.89 \pm 1.05^{\mathrm{a}}$ & $2.23 \pm 1.52^{\mathrm{ab}}$ & $0.97 \pm 0.76^{\mathrm{c}}$ \\
\hline Nitrite-nitrogen (mg.L $\left.\mathrm{L}^{-1}\right)$ & $\mathrm{NO}_{2}$ & $0.060 \pm 0.044^{\mathrm{a}}$ & $0.106 \pm 0.066^{\mathrm{ab}}$ & $0.110 \pm 0.079^{\mathrm{ab}}$ & $0.158 \pm 0.061^{\mathrm{b}}$ & $0.133 \pm 0.096^{\mathrm{ab}}$ \\
\hline Nitrate-nitrogen $\left(\mathrm{mg} . \mathrm{L}^{-1}\right)$ & $\mathrm{NO}_{3}$ & $0.43 \pm 0.25$ & $0.24 \pm 0.15$ & $0.28 \pm 0.15$ & $0.67 \pm 0.27$ & $0.44 \pm 0.30$ \\
\hline Total phosphorus (mg. $\mathrm{L}^{-1}$ ) & $\mathrm{TP}$ & $0.222 \pm 0.129$ & $0.264 \pm 0.060$ & $0.215 \pm 0.099$ & $0.259 \pm 0.047$ & $0.262 \pm 0.075$ \\
\hline Soluble reactive phosphorus $\left(\mathrm{mg} . \mathrm{L}^{-1}\right)$ & SRP & $0.102 \pm 0.078^{\mathrm{ab}}$ & $0.158 \pm 0.060^{\mathrm{b}}$ & $0.070 \pm 0.025^{\mathrm{a}}$ & $0.054 \pm 0.039^{\mathrm{a}}$ & $0.064 \pm 0.048^{\mathrm{a}}$ \\
\hline Total nitrogen $\left(\mathrm{mg} . \mathrm{L}^{-1}\right)$ & $\mathrm{TN}$ & $3.62 \pm 1.84^{\mathrm{a}}$ & $3.80 \pm 1.43^{\mathrm{ab}}$ & $5.68 \pm 1.78^{\mathrm{c}}$ & $5.48 \pm 1.89^{\mathrm{bc}}$ & $3.14 \pm 1.63^{\mathrm{a}}$ \\
\hline Chlorophyll-a $\left(\mu \mathrm{g} . \mathrm{L}^{-1}\right)$ & Chla & $40.6 \pm 22.8$ & $27.0 \pm 20.8$ & $22.6 \pm 11.0$ & $24.9 \pm 14.3$ & $23.7 \pm 12.3$ \\
\hline Total nitrogen: total phosphorus (mass) & TN:TP & $22.2 \pm 10.1^{\mathrm{ab}}$ & $17.1 \pm 10.7^{\mathrm{a}}$ & $29.1 \pm 9.4^{\mathrm{b}}$ & $21.9 \pm 7.2^{\mathrm{ab}}$ & $14.2 \pm 9.2^{\mathrm{a}}$ \\
\hline
\end{tabular}

For each parameter, if one of the letters is the same, there was no significant difference between the 2 years (Scheffe's test, $\alpha=0.05$ ). If the variable is not different among groups, then it is not marked with a letter. Monthly averaged values were used in the analysis ( $n=11$ for 2005 and $n=12$ for others).

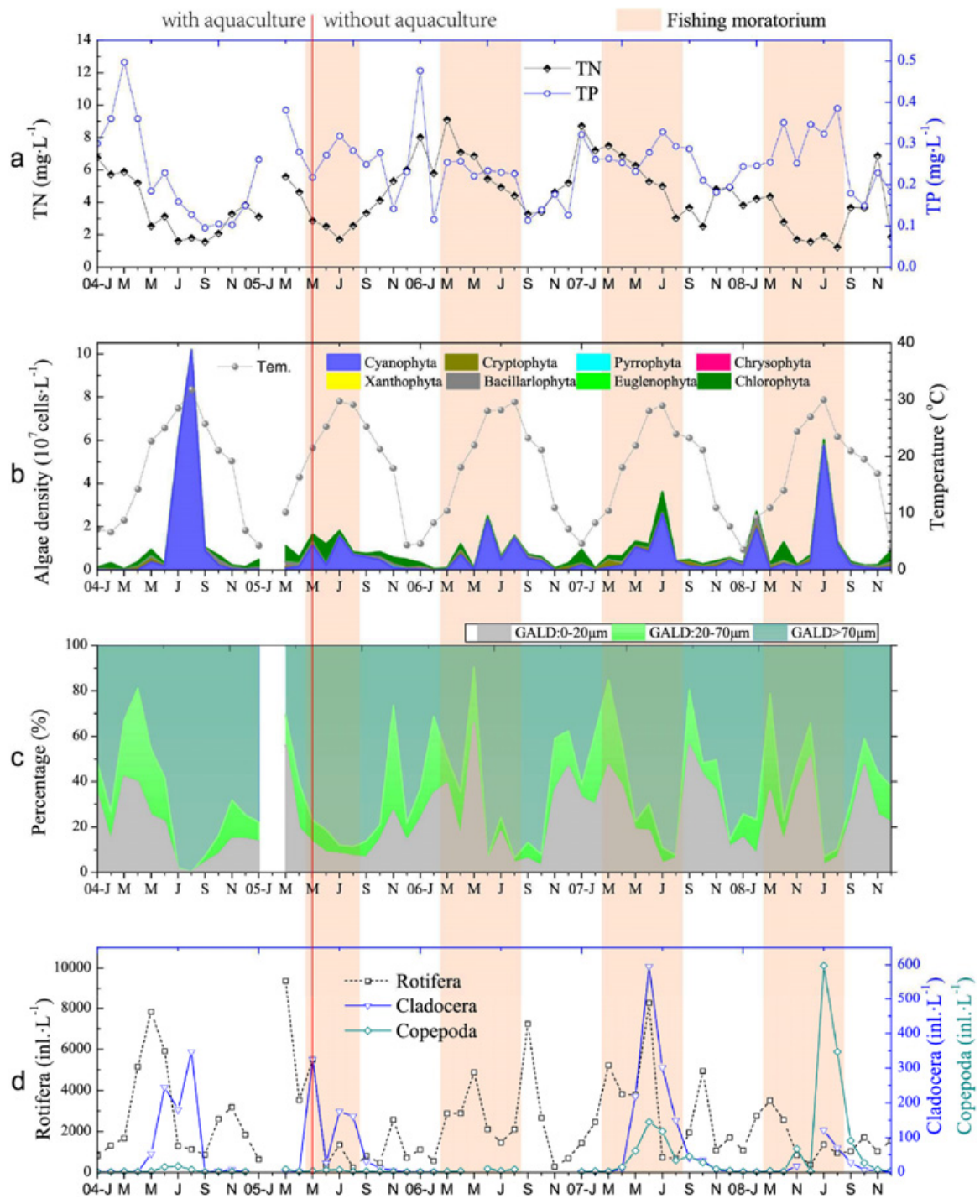

Fig. 2. Monthly dynamics of (a) TN and total phosphorus, (b) water temperature and algae density, (c) GALD (greatest axial length dimension) distribution, (d) zooplankton from 2004 to 2008 in Lake Dianshan. No sampling took place in February 2005. No data were recorded for Cladocera in January and February 2005, March to December 2006 or June 2008. No data were recorded for Copepoda in May or in September to December 2006. 


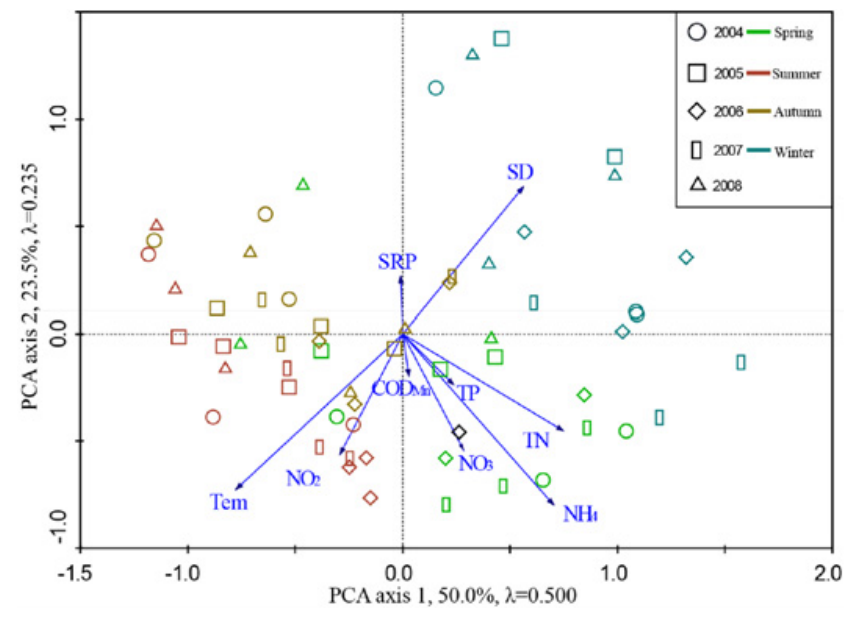

Fig. 3. Biplot of the first two axes of a principal components analysis of the environmental variables. The analysis explained $73.5 \%$ of the variance. Different geometric symbols represent different years. Different colours represent different seasons. Abbreviations for environmental variables are defined in Table 2.

More species not only from Chlorophyta and Bacillariophyta, but also from Cyanophyta were recorded after the cessation, leading to a significant increase in phytoplankton species richness (Table 3).

With regard to the phytoplankton density, a sharp reduction occurred concomitant with a decrease in chlorophyll-a after the cessation of aquaculture (Fig. 2, Table 2). The highest density dropped from $1.02 \times 10^{8}$ cells. $\mathrm{L}^{-1}$ in 2004 to $6.03 \times 10^{7}$ cells. $\mathrm{L}^{-1}$ during 2005-2008. This reduction was mainly attributed to the decrease in Cyanophyta because the annual highest values recorded in summers (June-August) were mainly due to the blooms of Cyanophyta, which accounted for $98 \%$ of the total phytoplankton density during the summer of 2004. After cessation, the annual highest Cyanophyta density as well as biomass decreased sharply in 2005 and then increased slowly until 2008 but remained significantly lower than the 2004 values (Figs. 2 and 4). In contrast, Chlorophyta, Bacillariophyta and Cryptophyta biomass increased in summers after the cessation of aquaculture, causing a marked decline of the ratio of Cyanophyta biomass to the total phytoplankton biomass (Fig. 5).

The dominant species exhibited strong seasonal changes, except for Cryptomonas erosa, which dominated throughout this study (Table 4). During warm periods (temperature $>20^{\circ} \mathrm{C}$ ), Cyanophyta species mostly dominated the phytoplankton community, with fewer species of Chlorophyta, Bacillariophyta, Cryptophyta and Euglenophyta. During the cold periods (temperature $<20^{\circ} \mathrm{C}$ ), however, more species of Chlorophyta, Bacillariophyta and other groups became dominant. The dominant species also changed after the cessation of aquaculture, mainly in warm periods. Microcystis flos-aquae, which produced toxic blooms, was predominant in 2004, forming $82 \%$ of the total phytoplankton biomass in high summer. However, other less harmful species of Cyanophyta or Chlorophyta, Bacillariophyta and Euglenophyta became dominant after the cessation of aquaculture. Microcystis spp. were rare in the first 2 years after the cessation, but they rebounded in the last 2 years of this study, representing more than $30 \%$ of the total phytoplankton biomass in high summer, though this amount is still less than in 2004.

Phytoplankton also changed in their cell size after the cessation of aquaculture, especially in the summers. The algae were divided into three groups based on the individual GALD (Fig. 2). During high summer, species with GALD $>70 \mu \mathrm{m}$ dominated the phytoplankton community, and they mainly consisted of colonies or filaments of Cyanophyta such as Microcystis or Phormidium. The relative proportion of these taxa decreased after the cessation of aquaculture. Species with GALD $<20 \mu \mathrm{m}$ tended to grow during cold seasons, and most of them were Chlorophyta, such as Chlamydomonas or Chlorella, as well as some Cryptophyta. They was only a small proportion of the total phytoplankton density during high summer in 2004, but their proportion increased after 2004. The intermediate group of $20 \mu \mathrm{m}<\mathrm{GALD}<70 \mu \mathrm{m}$, mainly composed of Chlorophyta, Cryptophyta and Bacillariophyta, peaked in March and November and changed little after the cessation of aquaculture.

The Shannon-Weiner diversity index $\left(H^{\prime}\right)$ showed a similar pattern of seasonal variation in different years. During each year, it peaked in early spring and late autumn and dropped in summer. Comparison of diversity between years indicated that phytoplankton diversity was significantly lower in $2004(1.78 \pm 0.77)$ than in 2005 and 2008, annually. The diversities in high summer (July and August) in 2004 were extremely and significantly lower than in other years (Fig. 6).

Table 3. Annual species richness of phytoplankton in Lake Dianshan (2004-2008).

\begin{tabular}{lrrrrr}
\hline Group & 2004 & 2005 & 2006 & 2007 & 31 \\
\hline Cyanophyta & 21 & 27 & 22 & 2008 \\
Cryptophyta & 3 & 2 & 2 & 3 & 1 \\
Pyrrophyta & 2 & 2 & 2 & 1 & 2 \\
Chrysophyta & 1 & 1 & 31 & 32 & 12 \\
Bacillariophyta & 28 & 27 & 14 & 81 \\
Euglenophyta & 17 & 81 & 1 & 3 \\
Chlorophyta & 76 & 3 & 158 & 3 \\
Xanthophyta & 0 & 175 & & 164 \\
Total & 148 & & & 172 \\
\hline
\end{tabular}




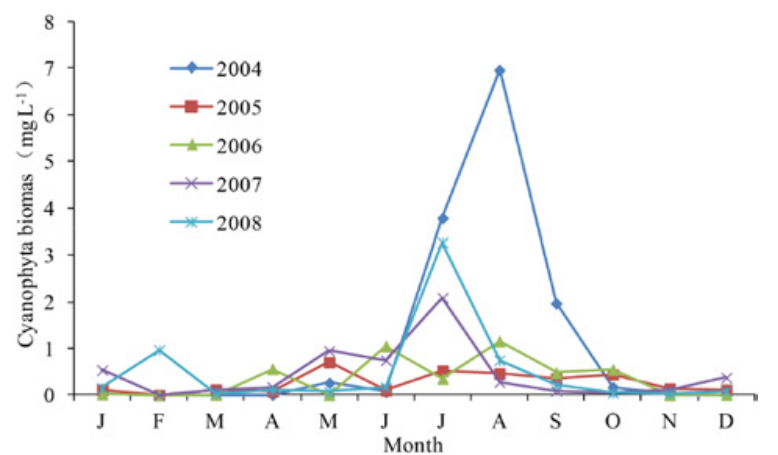

Fig. 4. Cyanophyta biomass $\left(\mathrm{mg} . \mathrm{L}^{-1}\right)$ in Lake Dianshan from 2004 to 2008.

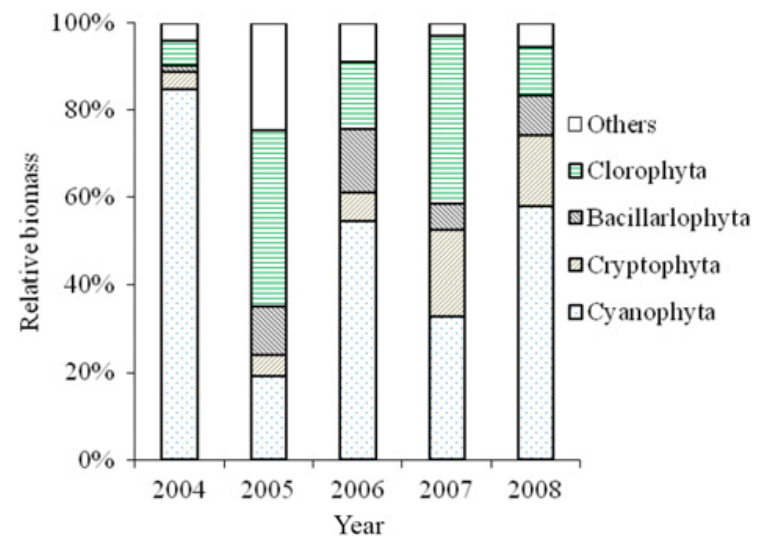

Fig. 5. Relative biomass (\%) of the different groups of phytoplankton in summers in Lake Dianshan from 2004 to 2008.

The relationship between physico-chemical environmental variables and phytoplankton species composition was investigated using CCA. All canonical axes were significant and cumulatively explained $26.5 \%$ of the variance in the species data. The biplots depict the relationships among these variables and dominant phytoplankton taxa (Fig. 7). The first CCA axis explained $9.4 \%$ of the variance $\left(\lambda_{1}=0.340 ; P=0.005\right)$, and the second CCA axis explained $4.1 \%$ of the variance $\left(\lambda_{2}=0.147\right.$, $P=0.001)$. The first axis represents a gradient from higher temperature in the positive direction and higher Secchi transparency in the negative direction. The second axis is most highly correlated with TN:TP, COD $\mathrm{Mn}_{\mathrm{n}}$ and $\mathrm{NO}_{2}$. The CCA highlights the importance of temperature in structuring the phytoplankton community, which contributed $30 \%$ of all canonical eigenvalues based on the variance partitioning. Therefore, the biplots mainly showed a seasonal species pattern. In general, samples collected in summer and autumn were associated with high abundance of Cyanophyta species, such as Microcystis, Merismopedia glauca and Spirulina, while Bacillariophyta, Cryptophyta or Euglenophyta species were found in high abundance in spring and winter. However, there were also some differences between years. Samples collected in high summer in 2004, which was characterized by more Microcystis, were far away from the others, and some samples collected in spring in 2004 included more C. erosa. The CCA also reveals the effects of TN:TP on the phytoplankton community. The ratio of TN:TP independently explains $4.0 \%$ of the total variance. The outbreak of Cyanophyta in summer in 2004, especially Microcystis, was associated with a low TN:TP. Moreover, the TN:TP was also lower in 2008. The Chlorophyta were more abundant in environments with higher TN:TP.

\section{Zooplankton}

Highly abundant rotifers and low biomass of planktonic crustaceans characterized the meta-zooplankton community in Lake Dianshan. Like phytoplankton, the

Table 4. Dominant species (biomass) of the phytoplankton in Lake Dianshan during 2004-2008.

\begin{tabular}{|c|c|c|c|c|c|}
\hline Jan.-Apr. 2004 & $\begin{array}{l}\text { Nov. 2004-Apr. } \\
2005\end{array}$ & $\begin{array}{l}\text { Nov. } 2005-A p r . \\
2006\end{array}$ & $\begin{array}{l}\text { Nov. 2006-Apr. } \\
2007\end{array}$ & $\begin{array}{c}\text { Nov. } 2007-A p r . \\
2008\end{array}$ & $\begin{array}{c}\text { Nov.-Dec. } \\
2008\end{array}$ \\
\hline$\overline{\text { Cryptomonas erosa }}$ & C. erosa & Phormidium sp. & C. erosa & P. faveolarum & C. erosa \\
\hline Synedra acus & Gonyostomum semen & C. erosa & Tribonema minus & P. tепие & S. ulna \\
\hline Chlamydomonas sp. & Aulacoseira granulate & Ceratium hirundinella & S. acus & C. erosa & \\
\hline Ulothrix sp. & A. granulata var. & Cymatopleura solea & Chlamydomonas spp. & Synedra sp. & \\
\hline & angustissima & Chlamydomonas sp. & & S. acus & \\
\hline & Cyclotella bodanica & Pediastrum tetras & & S. ulna & \\
\hline & S. acus & Ulothrix sp. & & Euglena oxyuris & \\
\hline & Euglena sp. & & & Chlamydomonas sp. & \\
\hline & Ulothrix sp. & & & V. aurens & \\
\hline
\end{tabular}

\begin{tabular}{|c|c|c|c|c|}
\hline May-Oct. 2004 & May-Oct. 2005 & May-Oct. 2006 & May-Oct. 2007 & May-Oct. 2008 \\
\hline$\overline{\text { M.flos-aquae }}$ & Merismopedia glauca & M. glauca & M. flos-aquae & M. wesenbergii \\
\hline Oscillatoria $\mathrm{sp}$. & Phormidium corium & Spirulina sp. & Oscillatoria sp. & M. aeruginosa \\
\hline \multirow[t]{5}{*}{ C. erosa } & Lyngbya limnetica & Oscillatoria sp. & P. tenue & P. faveolarum \\
\hline & C. erosa & P. corium & C. erosa & C. erosa \\
\hline & S. acus & C. erosa & Chlamydomonas sp. & Synedra acus \\
\hline & Phacus longicauda & Chlamydomonas sp. & Pandorina morum & Pinnularia sp. \\
\hline & $\begin{array}{l}\text { Oocystis elliptica } \\
\text { Desmidium baileyi }\end{array}$ & & Volvox aurens & E. oxyuris \\
\hline
\end{tabular}




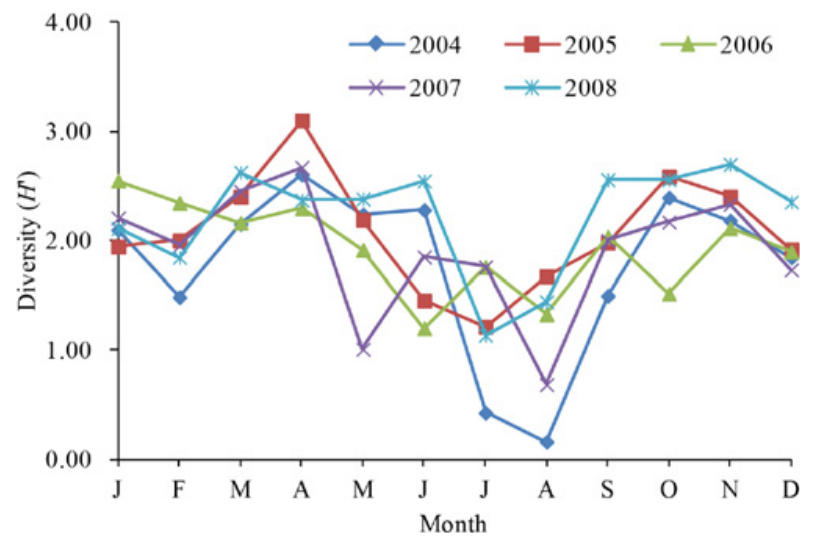

Fig. 6. Diversity in Lake Dianshan from January 2004 to December 2008.

zooplankton community also exhibited strong seasonality. Rotifer abundance peaked twice per year. The first peak occurred in spring, often in May, and the second occurred in autumn, often in September or October (Fig. 2), and dropped sharply in June in most cases. However, the planktonic crustaceans changed in different ways. Cladocerans and copepods often grew in summer and peaked only once, in June or August.

Zooplankton also changed after the cessation of aquaculture. Rotifer abundance decreased soon after the cessation but increased in 2007 and then decreased again in 2008. Cladocera changed similarly, though no data were recorded during 2006. Copepoda changed in other ways. Copepod abundance was extremely low (0.068 mg d.w.L $\left.{ }^{-1}\right)$ in 2004 but soared in 2007 and 2008 (1.02 mg d.w.L ${ }^{-1}$ ) (Fig. 2). Considering rotifers' limited ability to consume algae, we used the cladoceran and copepod carbon content to calculate the potential grazing pressure on the phytoplankton. Generally, higher ratios of zooplankton carbon content (C-zoo) to phytoplankton carbon content (C-phyto) were observed after the cessation of aquaculture, especially in high summer (Fig. 8).

\section{Discussion}

\section{Phytoplankton and water quality response to the cessation of cage aquaculture}

Generally, cage aquaculture has a negative effect on water quality because it can increase water nutrient concentration through unconsumed food and fish excreta being released directly into the water column. When cage aquaculture ceased, a decrease in the nutrient level was expected. However, no significant decrease in nutrient concentrations was observed after the cessation of aquaculture, and some nutrients even increased. This was mainly due to the large nutrient input by the upstream inflow. The inflow, which annually brought about $7000 \mathrm{t}$ of nitrogen and $350 \mathrm{t}$ of phosphorus into the lake, accounted for about $90 \%$ of the total nutrient load in Lake Dianshan in recent years (Lin et al., 2010). Therefore, nutrient concentrations in the lake were mainly
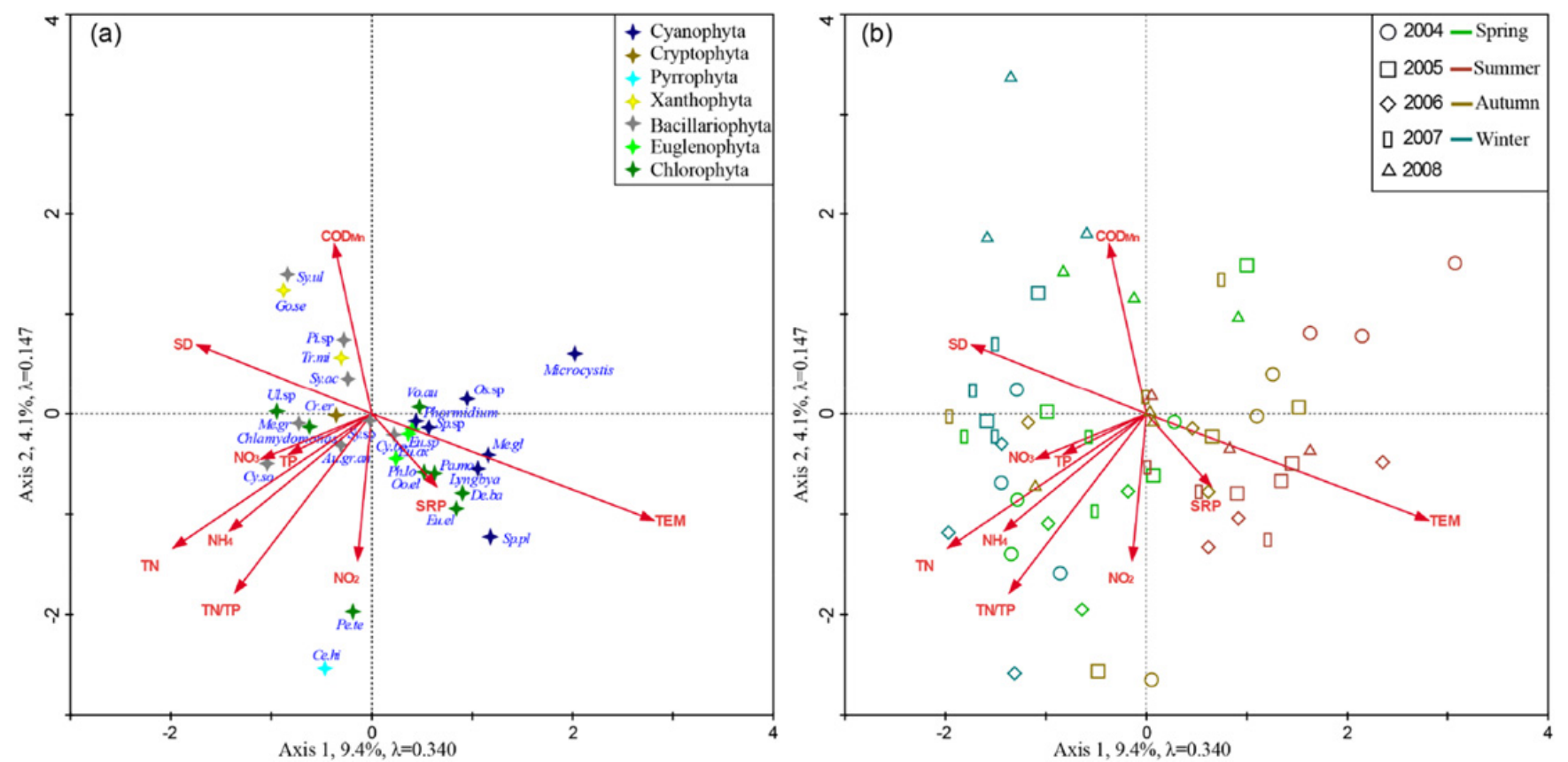

Fig. 7. Correlation biplots based on CCA depicting the influence of environmental variables on Lake Dianshan phytoplankton data, 2004-2008: (a) with species and environmental variables, (b) with samples and environmental variables. Axes 1 and 2 cumulatively account for $13.5 \%$ of the variation in phytoplankton community composition. Solid arrows represent the correlations of the environmental variables with the two CCA axes. Taxa are indicated by the first two letters of the names in Table 3 . Abbreviations for environmental variables are defined in Table 2. 


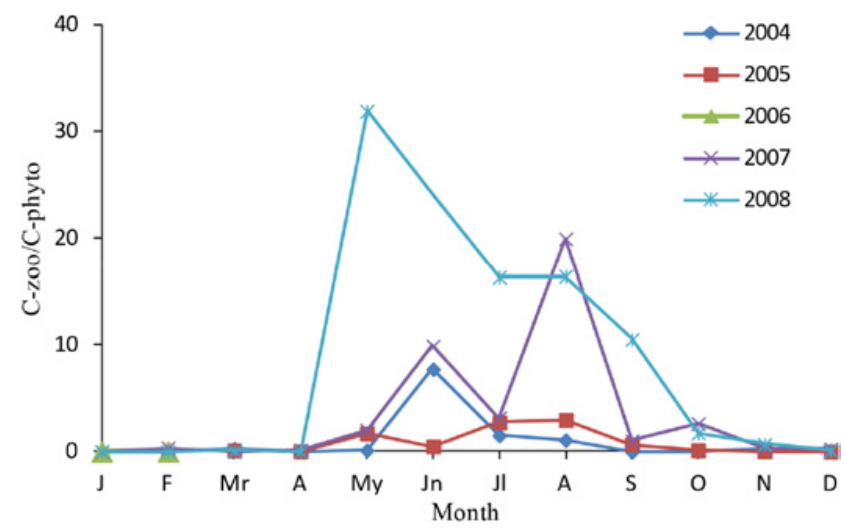

Fig. 8. Ratio of planktonic crustaceans carbon content (C-zoo) to phytoplankton carbon content (C-phyto) in Lake Dianshan. (No data were recorded on some sampling occasions; see Fig. 2.)

determined by the inflow, and cage aquaculture only played a small role in nutrient loading (Fig. 9). Furthermore, some of the aquaculture areas were near the outlet of the lake, and the aquaculture nutrient loading might be flushed downstream without spreading within the lake. In addition, the residual feed was not fully decomposed and mineralized to the water column due to the short hydraulic residence time of the lake (Shi and Liu, 1989). Moreover, the nutrients introduced through aquaculture may have sunk into the sediment and were likely released from the sediment when aquaculture ceased and the flux increased with increasing temperature ( $\mathrm{Su}$ et al., 2011). The TN and phosphorus in the sediment below the culture area were found to be significantly higher than in areas in which no aquaculture had taken place (Shi and Liu, 1989). The process of decomposition and release will continue for a long time even after the aquaculture ceased.

The cessation of aquaculture is important for nutrient reduction in the long run, though this effect did not appear in the current study. The aquaculture nutrient loading only contributed a little to the total input when its scale was small in 1985 (Fig. 9(a)). After 1992, the aquaculture developed rapidly, and its nutrient loading also increased approximately 17 -fold, but its proportion only increased fourfold because the inflow nutrient

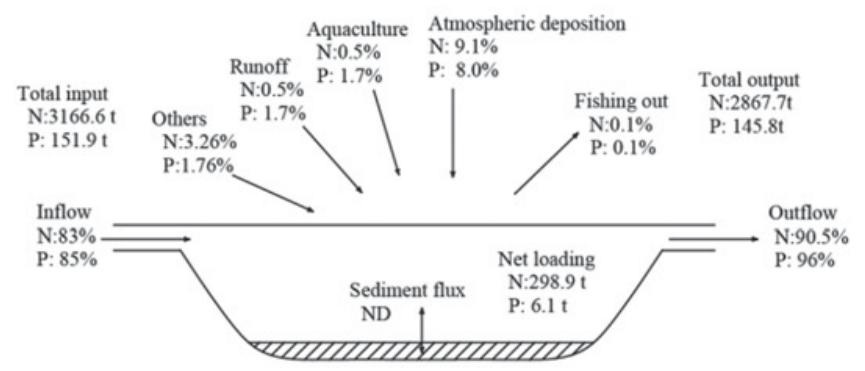

(a) loading increased (Fig. 9(b)). The allowable phosphorus loading to Lake Dianshan was approximately $26 \mathrm{t}$ (Lin et al., 2010), and the aquaculture net phosphorus loading was close to that. When the inflow nutrient loading is controlled, the aquaculture nutrient loading will occupy a large proportion if it continues.

However, the phytoplankton community changed markedly after the cessation despite the lack of significant change in nutrient level. For example, after the cessation of aquaculture, more phytoplankton species were observed, and the diversity increased. In addition, the algal density and biomass, especially the Cyanophyta, decreased markedly in summer. Furthermore, the dominant species altered from toxic Cyanophyta species to less harmful species. The large zooplankton, i.e., cladocerans and copepods, also increased, and they were regarded as important components to inhibit phytoplankton (Shapiro et al., 1975). All these changes indicated improvement in the ecological environment after the cessation. We can still consider the water quality to be improved despite the small change in the nutrient levels. The response of the phytoplankton community to this event may be amplified by synergistic interactions with other drivers of environmental change. For example, the change in the fish community structure will influence phytoplankton by trophic cascade interactions and top-down forces. Thus, the monitoring of phytoplankton was as important as the chemical analysis for assessing the overall water quality. We suggest that monthly monitoring is necessary and that during the warm season, twice-monthly monitoring is better. If the total phytoplankton or chlorophyll-a is reduced by $30 \%$, then the annual average diversity index increases by $15 \%$. In summer, if the diversity index increases by $80 \%$, harmful Cyanophyta are decreased by $50 \%$, and the proportion of Cyanophyta decreases by $50 \%$, we can still say that the water quality is improved.

\section{Relationship between phytoplankton community and environmental factors}

Phytoplankton community dynamics are controlled by physical and chemical forces and biotic interactions,

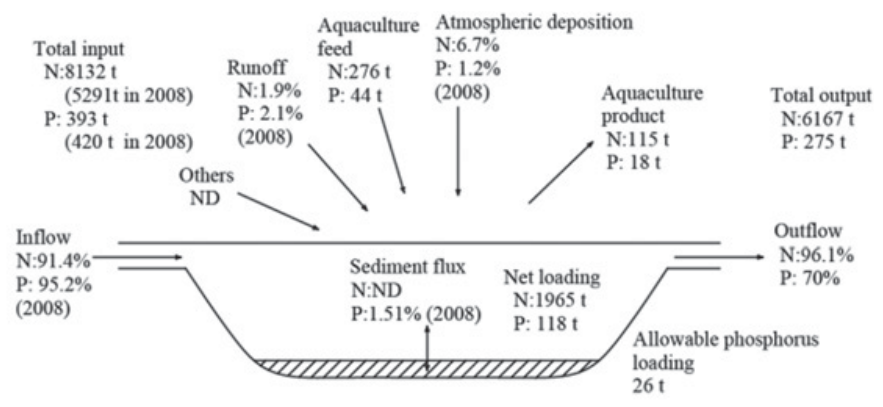

(b)

Fig. 9. Diagram of annual nutrient budget components in Dianshan Lake (a) during 1984-1985 (data from Kung and Ying, 1991) and (b) during 2000-2008 (data from Lin et al., 2010); data without explanation represent the average values for 2000-2007. ND: no data. 
and the dominant factors are known to be temperature, light penetration, nutrients, mixing and stratification (Richardson et al., 2000; Anneville et al., 2002). In any given case, a very few of these may be the most important structuring factors. The Secchi transparency was similar in different years, and there was no stratification in this shallow lake. Temperature was the most important factor in structuring the phytoplankton community in this lake as revealed by the CCA, but it was more closely related to the seasonal changes. In this study, the lake was characterized by high concentrations of nutrients (Table 2), and the concentrations were similar in different years and generally close to the limitations for phytoplankton growth (Schindler et al., 2008; Xu et al., 2010). Thus, it seemed that nutrient limitation worked poorly in this lake. However, the TN:TP ratio became a structuring factor, especially in summer, as suggested by the CCA. Cyanophyta grew fast in high temperatures, coinciding with a low TN:TP ratio, which is consistent with previous studies (Smith, 1983). The rebounding of Microcystis in 2008 may be attributed to the low ratio of TN:TP. The inflow ratio of TN:TP in 2008 was much lower than before, probably due to the increased rainfall during the monsoon. The amounts of precipitation from May through October were 675, 917, 634, 925 and $1144 \mathrm{~mm}$ for the years 2004 to 2008, respectively (Zhang et al., 2014). The inflow led to a low TN:TP ratio in the lake. This lake is still facing cyanobacterial blooms after the cessation of aquaculture. Thus, the cessation of aquaculture alone is insufficient to produce a substantial improvement in water quality. More attention should be paid to the control of external nutrient loading by inflow.

The changes in phytoplankton may be associated with the increased potential grazing pressure. Most cladocerans and some copepods graze on phytoplankton. Thus, they have a great effect on phytoplankton. The phytoplankton consisted mainly of large colonies and filaments with GALD $>70 \mu \mathrm{m}$ in summer of 2004 (Fig. 2), but the zooplankton showed more predation pressure on smaller phytoplankton species $(<40 \mu \mathrm{m})$ (Haney, 1987; Agasild et al., 2007; Bonecker et al., 2007; McCarthy et al., 2007). Grazers are often ineffective at preying on colonial Cyanophyta due to potential toxicity and/or gelatinous envelopes (Dokulil and Teubner, 2000). After cessation, the proportion of smaller phytoplankton increased, and more non-toxic species were present. This state of the ecological environment favoured the herbivorous zooplankton, leading to an increase in C-zoo/C-phyto. In turn, the greater potential grazing pressure helped to control the phytoplankton (Jeppesen et al., 1994).

The dramatic decline in the abundance of phytoplankton (esp. Cyanophyta) after the cessation of cage aquaculture may also be partially explained by the increased mixing because there was more exposure of the lake to wind and improved fluidity after the removal of the aquaculture installations. Both the installations for cage aquaculture and the fixed bamboo-hedge traps for catching fish emerged more than one metre from the water surface, which created barriers opposing the wind-induced current. The lake, situated in a plain, became exposed to wind when those barriers were removed after 2004. The open-water current and waves induced by wind and inflow increased. These waves may have caused a re-suspension of sediment in the surface layer, thus decreasing the average amount of light received by phytoplankton cells over the mixed layer (Pannard et al., 2007). This inhibited the growth of phytoplankton; re-suspended matter engulfs and buries algal cells during sedimentation. When enveloped by colloid matter, Microcystis loses buoyancy and sinks (Lee, 1989). In the current study, we did not have detailed data about current velocity and wave intensity, but we still have some support for this explanation. The densities of phytoplankton (Fig. 2) and chlorophyll-a were both highest in 2004, but water transparency was not the lowest (Table 2). The fact that the water transparency did not benefit from reductions in phytoplankton indicated that more non-algal matter was suspended in the water column after 2004. Furthermore, the waves could be attenuated from 30 to $5 \mathrm{~cm}$ by the installations, according to our crude measurements. The resuspension of sediment may also increase the nutrient flux from the sediment to the water column. However, the nutrients from the sediment contributed only a small part of the total nutrient loading, and the resuspended matter mainly existed as particles. The water nutrient concentration was also close to the algal growth limitation. Therefore, the influence of light attenuation was probably larger than the influence of nutrient flux.

\section{Fish stocking}

The cultivated fish, as well as fish released before and after the cessation of aquaculture, can impact phytoplankton communities directly or indirectly depending on their feeding habits, even though the primary purpose of fish stocking is to bolster and conserve fish resources. Most of the cultivated fish were herbivorous or omnivorous, and they had negative effects on the water quality in general. $C$. idella and $P$. pekinensis feed on submerged macrophytes, which are essential to maintain the water in a clear state. Other bottom-dwelling cyprinids, e.g., M. piceus and $C$. auratus, search for food in the sediment and return nutrient to the water column and accelerate the internal nutrient cycling. They are considered to act as nutrient pumps, so their presence tends to increase phytoplankton abundance (Canal et al., 2015).

The fish population was profoundly changed after the cessation of aquaculture because the released fish biomass was only $0.1 \%$ of the cultured fish. Most of the released fish were filter-feeding (Hypophthalmichthys molitrix and $A$.nobilis), as it was supposed that these fish may be helpful to control the Microcystis bloom via nontraditional biomanipulation strategies ( $\mathrm{Xie}$ and Liu, 2001), although evidence regarding the role of filterfeeding fish in biomanipulation is conflicting. Traditional biomanipulation strategies argue that planktivorous fishes should be removed because they reduce zooplankton levels 
(Shapiro et al., 1975). However, non-traditional biomanipulation strategies regard them as more herbivorous than omnivorous and maintain that their populations should be fostered, so that they can directly graze on cyanobacteria (Shapiro and Wright, 1984; Starling et al., 1998; Meijer et al., 1999; Mehner et al., 2004; Lu et al., 2006; Chen et al., 2009; Ke et al., 2009). Carnivorous fish, such as Siniperca chuatsi, Pelteobagrus fulvidraco and Erythroculter ilishaeformis, can reduce the population of zooplanktivorous fish, thereby increasing the densities of zooplankton. Omnivorous benthic cyprinid fish, such as C. carpio, C. auratus and H. maculatus, are considered nutrient pumps, as stated before. However, the fish released after the cessation of aquaculture may not have substantially affected the nutrient level and phytoplankton, considering the low density $\left(<2 \mathrm{~g} \cdot \mathrm{m}^{-3}\right)$.

\section{Conclusions}

The cessation of aquaculture in Lake Dianshan improved overall water quality despite only a minor change in nutrient concentration due to the large nutrient loading via inflow because profound changes occurred in the phytoplankton community, especially in summer. After the cessation of aquaculture, a reduction in phytoplankton abundance was observed, the species composition changed from potentially toxic species such as Microcystis to non-toxic species such as Merismopedia, and phytoplankton diversity increased. The changes were more closely associated with physical or biotic variables than with chemical variables. These results are relevant to water resource management. Firstly, this study demonstrates that the phytoplankton community is as important as routine chemical analysis in assessing overall water quality. Secondly, the control of external nutrient loading by inflow is more important than the cessation of aquaculture for a radical improvement of water quality.

Acknowledgements. This study was carried out with the financial support of the Shanghai Water Authority, the Shanghai Municipal Science and Technology Commission and the Shanghai Municipal Education Commission. We would like to thank the Dianshan Fishery Management Station for their help with sampling. We are also grateful to the people who helped with field and laboratory work: Wang Xucheng, Gai Jianjun, Fan Zhifeng, Zhang Junyi, Li Yan, Cheng Jinglei, Zhang Shihai, Lu Ziyuan, Zheng Xiaoyan, Wang Xianyun and Shi Rong. We thank Professor Erik Jeppesen for his suggestions regarding this manuscript. Thanks also go to the editor and three anonymous reviewers for their constructive criticism.

\section{References}

Agasild H., Zingel P., Tonno I., Haberman J. and Noges T., 2007. Contribution of different zooplankton groups in grazing on phytoplankton in shallow eutrophic Lake Vortsjarv (Estonia). Hydrobiologia, 584, 167-177.
Anneville O., Ginot V., Druart J.C. and Angeli N., 2002. Longterm study (1974-1998) of seasonal changes in the phytoplankton in Lake Geneva: a multi-table approach. J. Plank. Res., 24, 993-1007.

APHA, 1998. Standard Methods for the Examination of Water and Wastewater (20th edn), American Public Health Association, Washington, DC.

Behrendt H., 1990. The chemical-composition of phytoplankton and zooplankton in an eutrophic shallow lake. Arch. Hydrobiol., 118, 129-145.

Bonecker C.C., Nagae M.Y., Bletller M.C.M., Velho L.F.M. and Lansac-Toha F.A., 2007. Zooplankton biomass in tropical reservoirs in southern Brazil. Hydrobiologia, 579, 115-123.

Brander K.M., 2007. Global fish production and climate change. Proc. Natl. Acad. Sci. USA, 104, 19709-19714.

Canal J., Laffaille P., Gilbert F., Lauzeral C. and Buisson L., 2015. Influence of temperature on surface sediment disturbance by freshwater fish: a microcosm experiment. Ann. Limnol. - Int. J. Limnol., 51, 179-188.

Chen J.X. and Guan C.T., 2006. The present situation and development trend analysis of freshwater cage aquaculture in China. Sci. Fish Farm., 2006, 3-4.

Chen K.N., Bao C.H. and Zhou W.P., 2009. Ecological restoration in eutrophic Lake Wuli: a large enclosure experiment. Ecol. Eng., 35, 1646-1655.

Chiang S.-C. and Du N.-S., 1979. Fauna Sinica, Crustacea, Freshwater Cladocera, Science Press, Beijing.

Culver, D.A., Boucherle M.M., Bean D.J. and Fletcher J.W., 1985. Biomass of freshwater crustacean zooplankton from length-weight regressions. Can. J. Fisher. Aquat. Sci., 42, 1380-1390.

Ding W.X., Shen H.M., Zhu H.G., Lee B.L. and Ong C.N., 1999. Genotoxicity of microcystic cyanobacteria extract of a water source in China. Mutat. Res. - Genet. Toxicol. Environ. Mutagen., 442, 69-77.

Dokulil M.T. and Teubner K., 2000. Cyanobacterial dominance in lakes. Hydrobiologia, 438, 1-12.

Dumont H., Van de Velde I. and Dumont S., 1975. The dry weight estimate of biomass in a selection of Cladocera, Copepoda and Rotifera from the plankton, periphyton and benthos of continental waters. Oecologia, 19, 75-97.

Figueredo C.C. and Giani A., 2005. Ecological interactions between Nile tilapia (Oreochromis niloticus, L.) and the phytoplanktonic community of the Furnas Reservoir (Brazil). Freshw. Biol., 50, 1391-1403.

Guo L.G. and Li Z.J., 2003. Effects of nitrogen and phosphorus from fish cage-culture on the communities of a shallow lake in middle Yangtze River basin of China. Aquaculture, 226, 201-212.

Guo L.G., Li Z.J., Xie P. and Ni L.Y., 2009. Assessment effects of cage culture on nitrogen and phosphorus dynamics in relation to fallowing in a shallow lake in China. Aquacult. Int., 17, 229-241.

Haney J.F., 1987. Field studies on zooplankton-cyanobacteria interactions. N. Z. J. Mar. Freshw. Res., 21, 467-475.

Hansson L.A., Annadotter H., Bergman E., Hamrin S.F., Jeppesen E., Kairesalo T., Luokkanen E., Nilsson P.Å., Søndergaard M. and Strand J., 1998. Biomanipulation as an application of food-chain theory: constraints, synthesis, and recommendations for temperate lakes. Ecosystems, 1, $558-574$. 
Hillebrand H., Dürselen C.-D., Kirschtel D., Pollingher U. and Zohary T., 1999. Biovolume calculation for pelagic and benthic microalgae. J. Phycol., 35, 403-424.

$\mathrm{Hu}$ H. and Wei Y., 2006. The Freshwater Algae of China: Systematics, Taxonomy and Ecology, Science Press, Beijing.

Hu H.J., Li Y.Y., Wei Y.X., Zhu H.Z., Chen J.Y. and Shi Z.X., 1980. The Freshwater Algae of China, Shanghai Science and Technology Press, Shanghai.

Jeppesen E., Sondergaard M., Kanstrup E., Petersen B., Eriksen R.B., Hammershoj M., Mortensen E., Jensen J.P. and Have A., 1994. Does the impact of nutrients on the biological structure and function of brackish and fresh-water lakes differ. Hydrobiologia, 275, 15-30.

Jin X. and Tu Q., 1990. Standard Methods for Observation and Analysis in Lake Eutrophication (2nd edn), Chinese Environmental Science Press, Beijing.

Ke Z.X., Xie P. and Guo L.G., 2009. Impacts of two biomanipulation fishes stocked in a large pen on the plankton abundance and water quality during a period of phytoplankton seasonal succession. Ecol. Eng., 35, 1610-1618.

Kung H.-T. and Ying L.-G., 1991. A study of lake eutrophication in Shanghai, China. Geogr. J., 157, 45-50.

Latja R. and Salonen K., 1978. Carbon analysis for the determination of individual biomass of planktonic animals. Verhandlungen der Internationalen Vereinigung für Theoretische und Angewandte Limnologie, 20, 2556-2560.

Lazzaro X., Bouvy M., Ribeiro R.A., Oliviera V.S., Sales L.T., Vasconcelos A.R.M. and Mata M.R., 2003. Do fish regulate phytoplankton in shallow eutrophic Northeast Brazilian reservoirs? Freshw. Biol., 48, 649-668.

Lee R.E., 1989. Phycology (2nd edn), Cambridge University Press, Cambridge, New York.

Lepš J. and Šmilauer P., 2003. Multivariate Analysis of Ecological Data Using CANOCO, Cambridge University Press, Cambridge, UK, New York.

Lin W.Q., Lu S.Q. and Chen Y.Z., 2010. An application of ecodynamic model in evaluating eutrophication control measures for Dianshan lake in Shanghai. Shanghai Environ. Sci., $29,1-10$.

Liu J.S., Cui Y.B. and Liu J.K., 1997. Advances in studies on the effect of cage culture on the environment. Acta Hydrobiol. Sin., 21, 174-184.

Lu K.H., Jin C.H., Dong S.L., Gu B.H. and Bowen S.H., 2006. Feeding and control of blue-green algal blooms by tilapia (Oreochromis niloticus). Hydrobiologia, 568, 111-120.

Lu M., Xie P., Tang H., Shao Z. and Xie L., 2002. Experimental study of trophic cascade effect of silver carp (Hypophthalmichthys molitrixon) in a subtropical lake, Lake Donghu: on plankton community and underlying mechanisms of changes of crustacean community. Hydrobiologia, 487, 19-31.

McCarthy M.J., Lavrentyev P.J., Yang L.Y., Zhang L., Chen Y.W., Qin B.Q. and Gardner W.S., 2007. Nitrogen dynamics and microbial food web structure during a summer cyanobacterial bloom in a subtropical, shallow, well-mixed, eutrophic lake (Lake Taihu, China). Hydrobiologia, 581, 195-207.

McCauley E., 1984. The estimation of the abundance and biomass of zooplankton in samples. In: Downing J.A. and Rigler F.H. (eds.), A Manual on Methods for the Assessment of Secondary Productivity in Freshwaters, Blackwell Scientific Publications, Oxford, 228-265.
Mehner T., Arlinghaus R., Berg S., Dorner H., Jacobsen L., Kasprzak P., Koschel R., Schulze T., Skov C., Wolter C. and Wysujack K., 2004. How to link biomanipulation and sustainable fisheries management: a step-by-step guideline for lakes of the European temperate zone. Fisher. Manage. Ecol., 11, 261-275.

Meijer M.L., de Boois I., Scheffer M., Portielje R. and Hosper H., 1999. Biomanipulation in shallow lakes in The Netherlands: an evaluation of 18 case studies. Hydrobiologia, 408, 13-30.

Nash C.E., 2001. The net-pen salmon farming industry in the Pacific Northwest. U.S. Department of Commerce, NOAA Technical Memorandum NMFS-NWFSC-49.

Naylor R.L., Goldburg R.J., Primavera J.H., Kautsky N., Beveridge M.C.M., Clay J., Folke C., Lubchenco J., Mooney H. and Troell M., 2000. Effect of aquaculture on world fish supplies. Nature, 405, 1017-1024.

Olin M., Rask M., Ruuhijarvi J., Keskitalo J., Horppila J., Tallberg P., Taponen T., Lehtovaara A. and Sammalkorpi I., 2006. Effects of biomanipulation on fish and plankton communities in ten eutrophic lakes of southern Finland. Hydrobiologia, 553, 67-88.

Pannard A., Bormans M. and Lagadeuc Y., 2007. Short-term variability in physical forcing in temperate reservoirs: effects on phytoplankton dynamics and sedimentary fluxes. Freshw. Biol., 52, 12-27.

Perrow M.R., Meijer M.L., Dawidowicz P. and Coops H., 1997. Biomanipulation in the shallow lakes: state of the art. Hydrobiologia, 342, 355-365.

Pinto-Coelho R., Pinel-Alloul B., Méthot G. and Havens K.E., 2005. Crustacean zooplankton in lakes and reservoirs of temperate and tropical regions: variation with trophic status. Can. J. Fisher. Aquat. Sci., 62, 348-361.

Richardson T.L., Gibson C.E. and Heaney S.I., 2000. Temperature, growth and seasonal succession of phytoplankton in Lake Baikal, Siberia. Freshw. Biol., 44, 431-440.

Schindler D.W., Hecky R.E., Findlay D.L., Stainton M.P., Parker B.R., Paterson M.J., Beaty K.G., Lyng M. and Kasian S.E.M., 2008. Eutrophication of lakes cannot be controlled by reducing nitrogen input: results of a 37-year whole-ecosystem experiment. Proc. Natl. Acad. Sci. USA, 105, 11254-11258.

Shapiro J. and Wright D.I., 1984. Lake restoration by biomanipulation: round Lake, Minnesota, the first two years. Freshw. Biol., 14, 371-383.

Shapiro J., Lamarra V.A. and Lynch M., 1975. Biomanipulation: an ecosystem approach to lake restoration. In: Brezonik P.L. and Fox J.L. (eds.), University of Florida, Gainesville, 85-96.

Shen C.J., 1979. Fauna sinica, Crustacea, Freshwater Copepoda, Science Press, Beijing.

Shi M. and Liu H., 1989. Effects of cage aquaculture on water quality in Dianshan Lake. Rural Eco-environ., 3, 7-11.

Sin Y. and Jeong B., 2015. Short-term variations of phytoplankton communities in response to anthropogenic stressors in a highly altered temperate estuary. Estuar. Coast. Shelf Sci., 156, 83-91.

Smith V.H., 1983. Low nitrogen to phosphorus ratios favor dominance by blue-green algae in lake phytoplankton. Science, 221, 669-671.

Starling F., Beveridge M., Lazzaro X. and Baird D., 1998. Silver carp biomass effects on the plankton community in paranoa 
reservoir (Brazil) and an assessment of its potential for improving water quality in lacustrine environments. Int. Rev. Hydrobiol., 83, 499-507.

State EPA of China, 2002. Monitoring and Analysis Methods for Water and Wastewater (4th edn), China Environmental Science Press, Beijing.

Su L., Lin W., Yang Y. and Zhu Y., 2011. Fluxes of nitrogen and phosphorus releasing from sediment in Dianshan Lake. Environ. Pollut. Control, 33, 32-35.

Wang J.J., 1961. The Freshwater rotifer Fauna of China, Science Press, Beijing.

Xie P. and Liu J., 2001. Practical success of biomanipulation using filter-feeding fish to control cyanobacteria blooms: a synthesis of decades of research and application in a subtropical hypereutrophic lake. Sci. World, 1, 337-356.

Xu H., Paerl H.W., Qin B.Q., Zhu G.W. and Gao G., 2010. Nitrogen and phosphorus inputs control phytoplankton growth in eutrophic Lake Taihu, China. Limnol. Oceanogr., $55,420-432$.
Xu Z., Lin X., Lin Q., Yang Y. and Wang Y., 2007. Nitrogen, phosphorus, and energy waste outputs of four marine cagecultured fish fed with trash fish. Aquaculture, 263, 130-141.

Zhang J., Zhang Y., Li Q., Yu M., Ren J., Li P. and Wang K., 2014. Analysis of precipitation variation characteristics in Shanghai City over period from 1971 to 2010. Water Resour. Prot., 30, 47-52.

Zhang M., Zhou Y., Xie P., Xu J., Li J., Zhu D. and Xia T., 2004. Impacts of cage-culture of Oreochromis niloticus on organic matter content, fractionation and sorption of phosphorus, and alkaline phosphatase activity in a hypereutrophic lake, People's Republic of China. Bull. Environ. Contamin. Toxicol., 73, 927-932.

Zhao S.-Y., Sun Y.-P., Lin Q.-Q. and Han B.-P., 2012. Effects of silver carp (Hypophthalmichthys molitrix) and nutrients on the plankton community of a deep, tropical reservoir: an enclosure experiment. Freshw. Biol., 58, 1-14.

Zhuge Y., Huang X. and Koste W., 1998. Rotifera recorded from China, 1893-1997, with remarks on their composition and distribution. Int. Rev. Hydrobiol., 83, 217-232. 